\title{
Use of winter cover crops improves maize productivity under reduced nitrogen fertilization: a long-term study
}

\author{
Jonatas Thiago Piva ${ }^{1, \star}$ (D), Felipe Bratti² (D), Jorge Luiz Locatelli3 (D), Ricardo Henrique Ribeiro² (D), \\ Marcos Renan Besen ${ }^{4}$ (D), Eduardo Brancaleoni ${ }^{5}$ (D), Djalma Eugênio Schmitt ${ }^{6}$ (D) \\ 1. Universidade Tecnológica Federal do Paraná - Departamento de Agronomia - Santa Helena (PR), Brazil. \\ 2. Universidade Federal do Paraná -Setor de Ciências Agrárias - Departamento de Solos e Engenharia Agrícola - Curitiba (PR), Brazil. \\ 3. Universidade de São Paulo - Escola Superior de Agricultura “Luiz de Queiroz" - Departamento de Ciência do Solo - Piracicaba (SP), Brazil. \\ 4. Universidade Estadual de Maringá -Centro de Ciências Agrárias - Departamento de Agronomia - Maringá (PR), Brazil. \\ 5. Serviço Nacional de Aprendizagem Rural - Assistente Técnico e Gerencial - Videira (SC), Brazil. \\ 6. Universidade Federal de Santa Catarina - Centro de Ciências Rurais - Departamento de Agricultura, Biodiversidade e Floresta - Curitibanos \\ (SC), Brazil. \\ Received: Apr. 15, 2020 | Accepted: Oct. 6, 2020 \\ Section Editor: Alberto Cargnelutti Filho \\ *Corresponding author: jonatas@utfpr.edu.br \\ How to cite: Piva, J. T., Bratti, F., Locatelli, J. L., Ribeiro, R. H., Besen, M. R., Brancaleoni, E. and Schmitt, D. E. (2021). Use of winter \\ cover crops improves maize productivity under reduced nitrogen fertilization: a long-term study. Bragantia, 80, e0621. https://doi. \\ org/10.1590/1678-4499.20200165
}

\begin{abstract}
The objective was to evaluate the effect of winter cover crops on the agronomic performance of maize during five crop seasons in a clayey Inceptisol with reduced mineral nitrogen $(N)$ inputs. The treatments were seven single cover crops: white oats (Avena sativa L.), black oats (Avena strigose Schreb.), ryegrass (Lolium multiflorum L.), canola (Brassica napus L.), vetch (Vicia sativa L.), fodder radish (Raphanus sativus L.) and red clover (Trifolium pratense L.); a mix (black oats + vetch) and a fallow. During summer, in succession to the cover crops, maize was grown under no-tillage. The attributes were evaluated in two stages of maize development: flowering (morphological components) and physiological maturation (yield components). Differences in morphological and yield variables were observed in all crop seasons, with emphasis on grain yield, number of grains per row (NGR) and ear length (EL). The use of vetch showed greater contribution to the development of maize in relation to the other cover crops used, promoting an increase in stem diameter (SD), EL and NGR in all crop seasons and directly reflecting in higher grain yield. On the other hand, when maize was grown under cover crops commonly used in southern Brazil, such as ryegrass and white oats, the yield was similar to fallow. The results showed that vetch promoted higher maize yields, probably by $\mathrm{N}$ mineralization, and reinforce the hypothesis that cover crops in the off-season can aggregate benefits to crops in succession, especially in terms of nutrition.
\end{abstract}

Key words: mineralization, poaceae, fabaceae, nutrient cycling, Zea mays L.

\section{INTRODUCTION}

Maize (Zea mays L.) is one of the pillars of Brazilian agribusiness. With a cultivated area of $\sim 17$ million hectares in the 2018/2019 crop season, Brazil is the second largest exporter in the world ( 29 million tons) (CONAB 2019; FAO 2019). This culture stands out as a basic component of the animal and human diet, responsible for the supply of fiber, carbohydrates, vitamins and proteins (Koehler and Wieser 2013). In recent years, the establishment of no-tillage management, the intensification of agricultural production systems, genetic improvement and nitrogen fertilization increased crop yields (Ciampitti and Vyn 2013). Despite this, the mean national productivity of 5,448 $\mathrm{kg} \cdot \mathrm{ha}^{-1}$ in the $2018 / 2019 \mathrm{crop}$ season 
(CONAB 2019) is still below the productive potential that the crop presents and far from countries such as the USA, that registered an average productivity of $10,482 \mathrm{~kg} \cdot \mathrm{ha}^{-1}$ in the 2018/2019 crop season (USDA 2020).

In this sense, the adoption of conservationist practices is necessary to maximize production in a safe, sustainable and low cost, being accessible to farmers. Therefore, alternatives such as the use of cover crops in the maize off-season can directly contribute to improve grain yield through the supply of nutrients, especially the nitrogen (N) (Balota et al. 2014). The supply of $\mathrm{N}$ is extremely important for species of the grass family (Poaceae), as this is the nutrient most absorbed by maize and contributes more effectively to grain yield (Ribeiro et al. 2018; Veloso et al. 2018).

In addition to nutrients supply, growing plants in the off-season favors the maintenance of soil cover, reduces erosion and infestations by spontaneous plants (Balbinot Júnior et al. 2008), intensifies nutrient cycling (Tiecher et al. 2017) and increases soil organic matter (SOM) (Veloso et al. 2018; Locatelli et al. 2020). Furthermore, its use in autumn/winter periods (e.g. soil cover or animal feed) has reduced one of the major obstacles to agricultural production, which is the fallow soil in the off-season of grains, a condition that directly contributes to system degradation (Palm et al. 2014). However, few studies have shown the adaptability of different cover crops to the different climatic conditions and what are the direct and indirect benefits of each species on the yield of subsequent crops, especially under conditions of high SOM content.

Among the main species of cover crops grown in the southern region of Brazil, black oats (Avena strigose Schreb.), fodder radish (Raphanus sativus L.) and common vetch (Vicia sativa L.) stand out (Aita 1997). The use of black oats as a cover plant can contribute to the increase of the addition of biomass and, due to its high $\mathrm{C} / \mathrm{N}$ ratio, it ends up resulting in low decomposition rates, which allows a long period of residence in the soil and a slow release of nutrients (Acosta et al. 2014). Despite this, maize growing in succession to black oats may present a reduction in grain yield when compared to growing in succession to legumes. This is called "negative priming effect" (Kuzyakov et al. 2000), characterized by immobilization and the slow release of $\mathrm{N}$ by oat straw, which is out of sync with the nutritional demand of maize (Silva et al. 2007).

Although there is a predominance of grasses in rotation/succession systems, legumes have also been widely used in agricultural systems due to the potential to form symbiotic associations with atmospheric $\mathrm{N}$-fixing bacteria, such as vetch. Its low $\mathrm{C} / \mathrm{N}$ ratio, combined with the presence of compounds with great solubility, favors rapid decomposition and mineralization, increasing the rapid availability of $\mathrm{N}$ in the soil (Assmann et al.2007); which can result in increases in maize productivity (Silva et al. 2007; Bisognin et al. 2014).

In addition to nutrients supply, there are plant species with a high capacity to cycle nutrients, as occurs with the fodder radish. Due to the aggressive root system, this crop can explore deep soil layers and promote the recycling of nutrients to the shallow layers (Silva et al. 2007, 2008). Lourente et al. (2007) observed that the highest maize productivity was obtained when the crop was sown in succession to the fodder radish, in the absence of topdressing fertilization. This species acts directly on the recycling of nutrients, mainly N (Silva et al. 2007) and K (Michelon et al. 2019), which are quickly released to the maize uptake.

Therefore, the use of plants that fix atmospheric $\mathrm{N}$ and/or can recycle the element from the deepest layers to the surface can be a strategy to supply the maize demand for $\mathrm{N}$. The use of mineral $\mathrm{N}$ applied to maize is rarely higher than $50 \%$ (Cabezas et al. 2004) due to the various loss pathways (Alva et al. 2006). The use of green manure can be efficient to enhance maize yield.

In this context, the establishment of a succession system that involves the use of cover crops capable of providing quality residues can increase the maize yield while the exclusive use of crops, such as grasses, can negatively affect the systems longterm production. Thus, the objective of this study was to evaluate the effect of winter cover crops species on the agronomic performance of maize under reduced mineral $\mathrm{N}$ inputs during five growing-seasons in southern Brazil.

\section{MATERIAL AND METHODS}

The study was carried out in the central region of the state of Santa Catarina, Brazil ( $27^{\circ} 16^{\prime} 26.55^{\prime \prime} \mathrm{S}$ and $50^{\circ} 30^{\prime} 14.41^{\prime \prime} \mathrm{W}$, $1050 \mathrm{~m}$ above sea level), and the soil is classified as clayey Inceptisol (Soil Survey Staff 2014). The climate, according to the Köppen classification, is subtropical Cfb, with an average annual temperature of $15^{\circ} \mathrm{C}$ and precipitation of $1500 \mathrm{~mm}$. Data on average air temperature and precipitation during the five growing seasons were collected in a digital weather station installed $4 \mathrm{~km}$ from the study site (Fig. 1). 

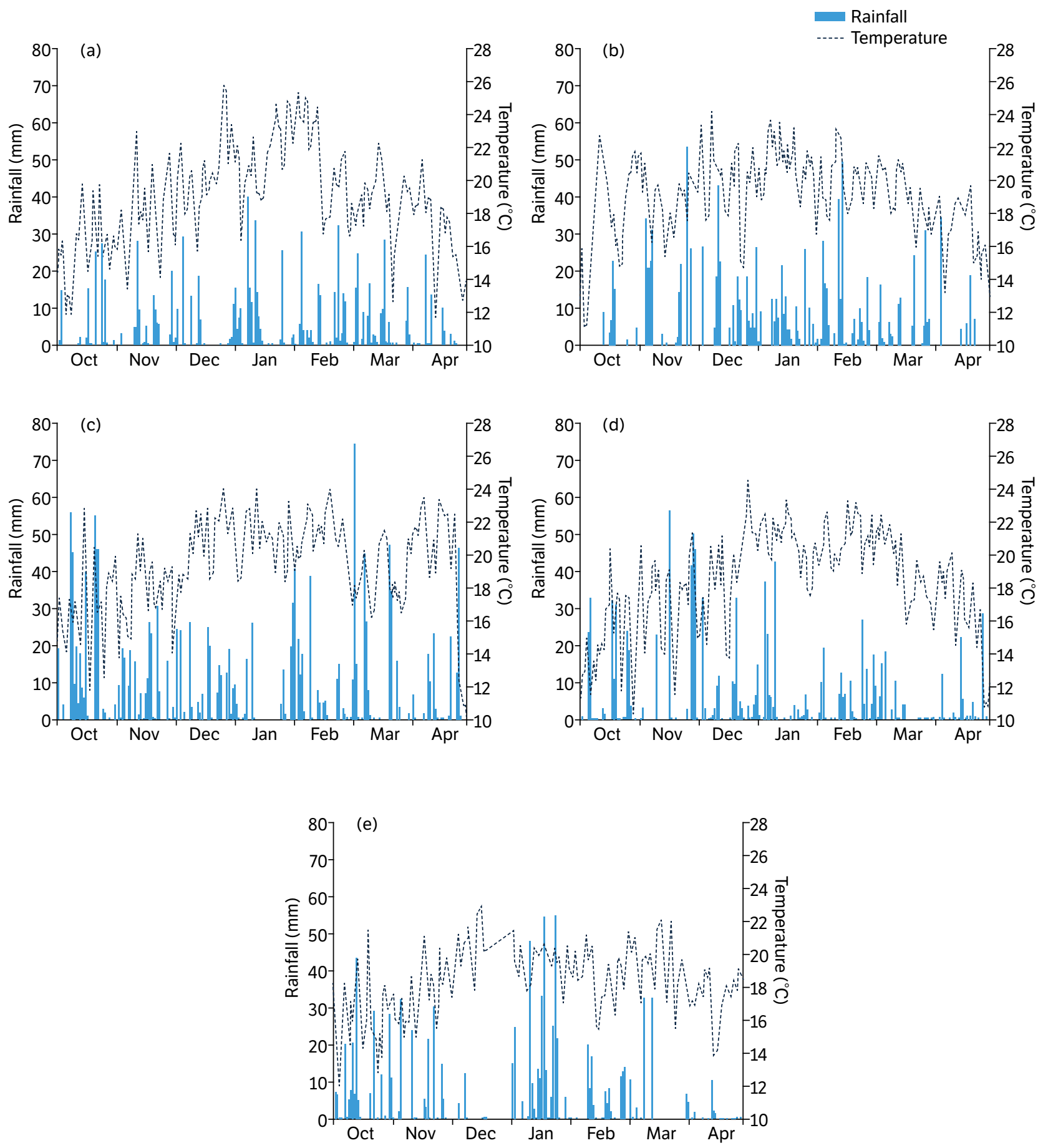

Figure 1. Precipitation and mean air temperature for the 2013/14 (a), 2014/15 (b), 2015/16 (c), 2016/17 (d) and 2017/18 (e) growing seasons.

Prior to the installation of the experiment, the area was being cultivated with black oats in winter and fallow in summer. The chemical characterization of the soil, in the $0-20 \mathrm{~cm}$ layer, was carried out prior to the implementation of the experiment and presented the following results: organic matter $(\mathrm{OM}): 44.23 \mathrm{~g} \cdot \mathrm{dm}^{-3}$; phosphorus $(\mathrm{P}): 10.7 \mathrm{mg} \cdot \mathrm{dm}^{-3}$; potassium $(\mathrm{K})$ : $39.93 \mathrm{mg} \cdot \mathrm{dm}^{-3} ; \mathrm{pH} \mathrm{CaCl}{ }^{2}: 6.3$; aluminum $\left(\mathrm{Al}^{3+}\right): 0 \mathrm{cmolc} \cdot \mathrm{dm}^{-3}$; calcium $\left(\mathrm{Ca}^{2+}\right): 8.35 \mathrm{cmolc} \cdot \mathrm{dm}^{-3}$; magnesium $\left(\mathrm{Mg}^{2+}\right)$ : $4.11 \mathrm{cmolc} \cdot \mathrm{dm}^{-3}$, base saturation: $79.8 \%$ and clay: $550 \mathrm{~g} \cdot \mathrm{kg}^{-1}$.

The experimental design was randomized blocks with nine treatments and four replicates, each experimental plot had the dimensions of $4 \times 4 \mathrm{~m}\left(16 \mathrm{~m}^{2}\right.$ ). The evaluated treatments were seven species of winter cover plants: white oats (Avena 
sativa L.), black oats (Avena strigosa), ryegrass (Lolium multiflorum L.), canola (Brassica napus L.), vetch (V. sativa L.), fodder radish (R. sativus L.) and red clover (Trifolium pratense L.); a mix (black oats + vetch) and a fallow. The fallow area was characterized by the maintenance of spontaneous vegetation with predominance of the following species: L. multiflorum L., Eleusine indica (L.) Gaertn. and Cyperus rotundus L. During the summer, maize was grown in succession to cover crops under no-tillage.

The winter cover crops sowing occurred in early June of each year (Table 1) with a seeder fertilizer, which demarcated the rows and deposited the fertilizer at $3.5 \mathrm{~cm}$ depth and with $300 \mathrm{~kg} \cdot \mathrm{ha}^{-1}$ of the formulated 00-18-18 (NPK). The seeds were manually and carefully arranged at $1.5 \mathrm{~cm}$ depth in the rows demarcated to simulate the no-tillage sowing with minimal soil disturbance in the densities of $80 \mathrm{~kg} \cdot \mathrm{ha}^{-1}$ of white oats, $7 \mathrm{~kg} \cdot \mathrm{ha}^{-1}$ of canola, $50 \mathrm{~kg} \cdot \mathrm{ha}^{-1}$ of ryegrass, $12 \mathrm{~kg} \cdot \mathrm{ha} \mathrm{h}^{-1} \mathrm{of}$ red clover, $80 \mathrm{~kg} \cdot \mathrm{ha}^{-1}$ of black oats, $12 \mathrm{~kg} \cdot \mathrm{ha}^{-1}$ of fodder radish, $50 \mathrm{~kg} \cdot \mathrm{ha}^{-1}$ of vetch and in the mix were used $30 \mathrm{~kg} \cdot \mathrm{ha}^{-1} \mathrm{of}$ vetch and $60 \mathrm{~kg} \cdot \mathrm{ha}^{-1}$ of black oats. After the emergence of $75 \%$ of the plants, $30 \mathrm{~kg} \cdot \mathrm{ha}^{-1}$ of $\mathrm{N}$-urea was applied in top dress. The flowering was considered as the end of cover crops cycle, when the area was desiccated with glyphosate-based (N-(phosphonomethyl) glycine) herbicide $\left(1,920 \mathrm{~g}\right.$ a.i.ha $\left.{ }^{-1}\right)$.

Data of cover crops dry matter (DM) production from 2013 to 2016 crop seasons were obtained from Locatelli et al. (2020) and updated in this work in 2017 winter season (Table 2). Before desiccation, the aboveground DM from cover crops was determined by clipping the plants at soil surface in an area of $0.5 \times 0.5 \mathrm{~m}$ and oven drying at $60^{\circ} \mathrm{C}$ until constant mass. Afterwards the dry residue was returned to the plots to maintain soil cover with the straw.

The maize sowing was carried out in a no-tillage system 30 days after desiccation of cover crops, using hybrids adapted to the region (Table 1). The spacing between rows was $0.45 \mathrm{~m}$ and the density was of 70,000 seeds.ha- ${ }^{-1}$. There was no application of fertilizers from nitrogen sources in order to assess the availability of this nutrient by cover crops decomposition only. Thus, the basal fertilization was carried out with $300 \mathrm{~kg} \cdot h \mathrm{~h}^{-1}$ of the fertilizer NPK 00-18-18 and the cultural treatments were carried out according to the technical recommendation for the cultivation of maize through periodic monitoring.

Table 1. General information on the conduction and establishing maize, in the five growing-seasons.

\begin{tabular}{cccccc}
\hline \multirow{2}{*}{ Management practices } & \multicolumn{4}{c}{ Growing seasons } \\
\cline { 2 - 6 } & $\mathbf{2 0 1 3 / 1 4}$ & $\mathbf{2 0 1 4 / 1 5}$ & $\mathbf{2 0 1 5 / 1 6}$ & $\mathbf{2 0 1 6 / 1 7}$ & $\mathbf{2 0 1 7 / 1 8}$ \\
\hline Cover crops sowing date & $06 / 08 / 2013$ & $06 / 02 / 2014$ & $06 / 08 / 2015$ & $07 / 08 / 2016$ & $06 / 15 / 2017$ \\
\hline Desiccation date & $10 / 14 / 2013$ & $10 / 25 / 2014$ & $09 / 22 / 2015$ & $10 / 02 / 2016$ & $10 / 03 / 2017$ \\
\hline Maize hybrid & DKB245 & SYN 7617 & 30F53 YHR & AG 9025 & 30 F53 YHR \\
\hline Maize sowing date & $11 / 08 / 2013$ & $11 / 12 / 2014$ & $10 / 20 / 2015$ & $10 / 31 / 2016$ & $10 / 20 / 2017$ \\
\hline Maize harvest date & $03 / 15 / 2014$ & $03 / 20 / 2015$ & $03 / 05 / 2016$ & $03 / 15 / 2017$ & $03 / 13 / 2018$ \\
\hline
\end{tabular}

Table 2. Mean ( \pm standard error) of dry matter production (kg.ha-1) from cover crops and fallow in the winter crop season from 2013 to 2017 , in a clayey Inceptsoil.

\begin{tabular}{cccccc}
\hline Treatment & $\mathbf{2 0 1 3}$ & $\mathbf{2 0 1 4}$ & $\mathbf{2 0 1 5}$ & $\mathbf{2 0 1 6}$ & $\mathbf{2 0 1 7}$ \\
\hline Vetch & $858.5 \pm 73.3$ & $1761.2 \pm 94.3$ & $2729.8 \pm 75.4$ & $4089.0 \pm 283.5$ & $3334.0 \pm 944.8$ \\
\hline Fodder radish & $995.0 \pm 79.54$ & $2200.0 \pm 132.7$ & $2521.3 \pm 57.0$ & $2099.7 \pm 193.5$ & $2677.1 \pm 434.2$ \\
\hline Fallow & $1806.1 \pm 154.7$ & $649.7 \pm 56.8$ & $1785.5 \pm 135.7$ & $3222.3 \pm 238.9$ & $1903.1 \pm 153.5$ \\
\hline Black oats & $1113.9 \pm 45.9$ & $2252.0 \pm 138.1$ & $2532.9 \pm 93.2$ & $6617.2 \pm 355.8$ & $2252.0 \pm 154.4$ \\
\hline Canola & $1105.5 \pm 113.7$ & $1754.4 \pm 199.5$ & $2144.6 \pm 18.1$ & $2380.4 \pm 124.3$ & $2112.9 \pm 274.5$ \\
\hline Mix & $1134.3 \pm 69.8$ & $1673.9 \pm 92.0$ & $3074 \pm 101.4$ & $3776.4 \pm 91.1$ & $3101.7 \pm 280.8$ \\
\hline White oats & $1065.4 \pm 55.8$ & $1699.6 \pm 127.7$ & $2478.1 \pm 110.9$ & $8007.2 \pm 15.1$ & $3369.6 \pm 234.1$ \\
\hline Ryegrass & $1113.1 \pm 74.0$ & $2665.6 \pm 212.9$ & $2352.1 \pm 58.8$ & $5113.6 \pm 140.1$ & $2054.3 \pm 130.1$ \\
\hline Red clover & $1264.6 \pm 66.9$ & $1650.7 \pm 80.5$ & $2324.5 \pm 95.5$ & $1549.4 \pm 124.1$ & $724.8 \pm 114.6$ \\
\hline
\end{tabular}

Data from 2013 to 2016 winter seasons were obtained from Locatelli et al. (2020). 
The evaluations were carried out in two stages of maize development, the first in the flowering (R1), when the morphological characters were evaluated, including plant height (PH), stem diameter (SD) and height of ear insertion (HEI). The yield components were evaluated in a second stage, during the physiological maturation stage (R6), being the number of grains per row (NGR), number of rows per ear (NRE), thousand grain mass (TGM), grain yield (GY) and ear length (EL). To obtain these variables, 10 plants were collected, disregarding the border. In determining yield components, the ears collected were included in the grain yield evaluation.

The data referring to the variables EL, HEI and PH were measured with a metric measuring tape, the SD using a digital pachymeter and the other variables (NGR and NRE) through counting. To determine the TGM, 250 individual grains were counted and weighted with a semi-analytical balance and the result extrapolated to one thousand grains. Grain yield was determined through the mass of grains harvested in the useful area of each plot, represented by a $4 \mathrm{~m}^{2}$ subplot. The results were corrected for the moisture content of $13 \%$ and extrapolated to $\mathrm{kg} \cdot \mathrm{ha}^{-1}$.

Data was submitted to the normality test (Shapiro-Wilk) and variance analysis $(\mathrm{p}<0.05)$. The means were compared using the Scott-Knott test $(\mathrm{p}<0.05)$, using the software R.

\section{RESULTS AND DISCUSSION}

The maize yield and morphological parameters were influenced by cover crops along the crop seasons evaluated (Fig. 2 and Table 3). In general, the yield was higher when maize was grown on the vetch residues (average of $8 \mathrm{Mg} \cdot \mathrm{ha}^{-1}$ ) in the five crops seasons and with an accumulated grain yield of $40,513 \mathrm{~kg} \cdot h \mathrm{a}^{-1}$, about $64 \%$ greater than fallow, $49-72 \%$ greater than grasses, $34-39 \%$ greater than other legumes or the mix and $40-41 \%$ greater than brassicas. This can be explained by the greater nutrition provided by the nutrients mineralization of vetch straw, mainly by the increase in the availability of $\mathrm{N}$, as this nutrient was not applied to maize mineral fertilization, promoting a direct effect on the increase of yields and on the morphological components of maize (Acosta et al. 2014). Magalhães et al. (2002) highlight that $\mathrm{N}$ plays a fundamental role in the storage and translocation of photoassimilates, with a direct impact on the increase in photosynthetic efficiency, enzyme activation and protein production, which has a direct impact on maize productivity.

It is estimated that for each ton of shoot dry matter produced by common vetch, $46 \mathrm{~kg}$ of $\mathrm{N}$ is accumulated (Borkert et al. 2003). Amado et al. (2002) observed that the average contribution of $\mathrm{N}$ by vetch straw is $120 \mathrm{~kg} \cdot \mathrm{ha}^{-1}$, but it can vary from 50 to $200 \mathrm{~kg} \cdot \mathrm{ha}^{-1}$. Similarly, in this study it was estimated an annual input of N, based vetch straw production (Table 2) around $150 \mathrm{~kg} \cdot \mathrm{ha}^{-1}$ in the last three growing seasons, promoting an adequate supply of $\mathrm{N}$ to maize development.

The superiority of vetch over all maize morphological and yield parameters during the five crop seasons resulted in the highest maize grain yield (Fig. 2). The intrinsic characteristics of this leguminous cover crop allowed the $\mathrm{N}$ fixed in autumn/winter to be made available during the maize development. These effects are more pronounced in years with adverse weather conditions, such as 2016/17 and 2017/2018 crop seasons, with periods of drought, high temperatures and high precipitation conditions over short periods of time (Figs. 1d, e), where vetch promoted higher yields than the other cover crops (Figs. 2d, e). In crop seasons with normal weather conditions (Figs. 1a, b, c), the effect of cover crops might have been masked, as the availability of water and the mineralization of plant residues present on the soil surface, regardless of quality, allied to the high SOM content $\left(44.23 \mathrm{~g} \cdot \mathrm{dm}^{-3}\right)$, contributed to increase maize yields (Kramberger et al. 2009), yet vetch promoted higher yields.

The use of vetch as cover crop promoted the highest values of maize morphological parameters strongly related to an adequate nutritional status and higher yields. For instance, vetch increased EL and NGR (Table 3) in all crop seasons (except 2016/2017), increased the PH in three (2014/15, 2016/17 and 2017/18) of the five crops and increased the SD in the first and last crop seasons. The low $\mathrm{C} / \mathrm{N}$ ratio of residues (11-16, Acosta et al. (2014)) favors rapid decomposition and consequently promotes greater availability of $\mathrm{N}$ in soil (50-60\% of the $\mathrm{N}$ accumulated is released in the first 30 days after management), showing a short period of contribution to the maize crop (Aita and Giacomini 2003; Acosta et al. 2014). The increase in $\mathrm{PH}$ can be a direct effect of the $\mathrm{N}$ released by vetch, especially in the early stages of maize development, where the main 

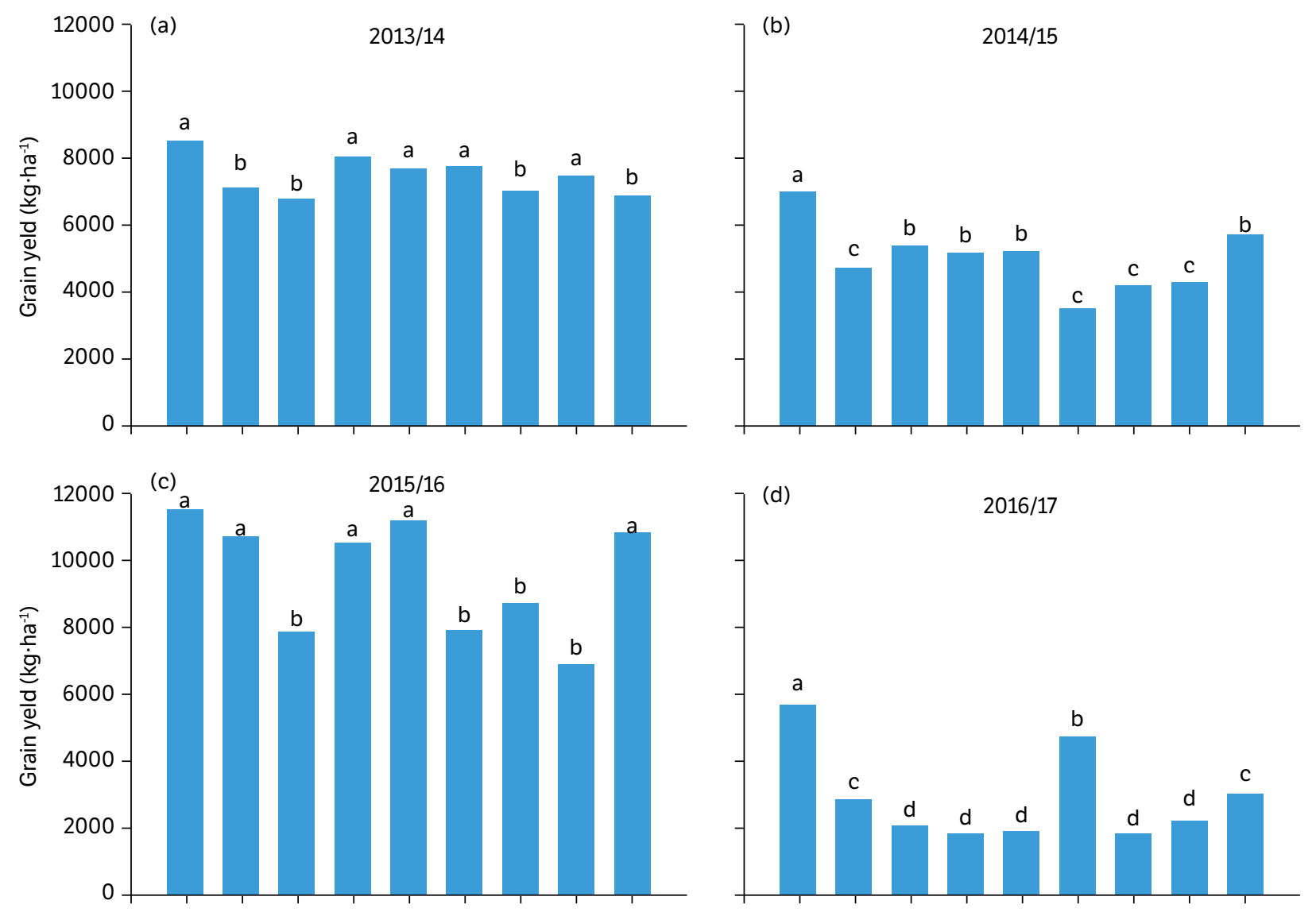

(d)

$2016 / 17$
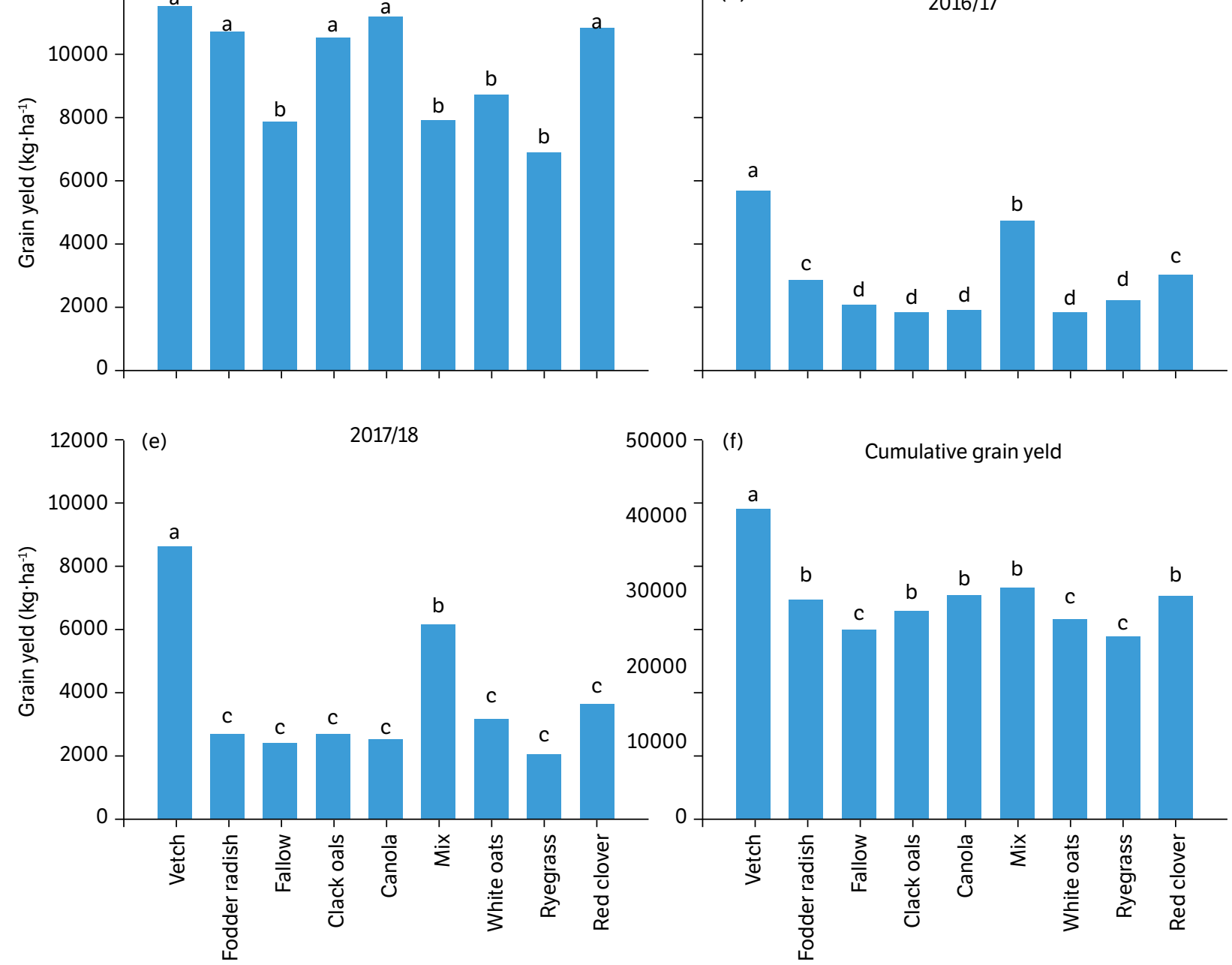

Figure 2. Maize yield grown under cover crops and fallow in five crop seasons 2013/14(a), 2014/15(b), 2015/16(c), 2016/17(d), 2017/18 (e) and cumulative grain yield ( $f$ ) in a clayey Inceptisol. Means followed by the same letter do not differ significantly by the Scott-Knott test at $5 \%$ probability.

parameters of crop yield are defined. Santos et al. (2010) observed that green manure had a positive influence on PH even in the absence of nitrogen fertilization, as observed in this study.

The increase in the availability of $\mathrm{N}$ in the soil by growing vetch also contributed to the development of other variables as SD (Table 3), which is an important morphological characteristic for the support of aerial structures and mainly for 
Table 3. Selected morphological and yield components of maize grown under cover crops and fallow in the crop seasons from $2013 / 14$ to 2017/18 in a clayey Inceptisol.

\begin{tabular}{|c|c|c|c|c|c|c|c|c|c|}
\hline & Vetch & Fodder radish & Fallow & Black oats & Canola & Mix & White oats & Ryegrass & Red clover \\
\hline \multicolumn{10}{|c|}{$2013 / 14$} \\
\hline $\mathrm{PH}$ & $2.04^{\mathrm{ns}}$ & 2.08 & 2.07 & 2.02 & 2.04 & 2.07 & 2.00 & 2.00 & 2.04 \\
\hline SD & $24.92 a$ & $21.32 b$ & $21.57 b$ & $22.70 b$ & $21.72 b$ & $22.70 b$ & $22.32 b$ & $22.53 b$ & $22.55 b$ \\
\hline NGR & $30.65 a$ & $22.30 \mathrm{~b}$ & $20.65 b$ & $24.00 \mathrm{~b}$ & $21.55 b$ & $22.54 b$ & $22.35 b$ & $23.00 \mathrm{~b}$ & $24.75 b$ \\
\hline EL & $15.52 a$ & $12.77 b$ & $11.95 b$ & $13.62 b$ & $12.72 b$ & $13.35 b$ & $12.27 \mathrm{~b}$ & $13.35 b$ & $12.65 b$ \\
\hline \multicolumn{10}{|c|}{$2014 / 15$} \\
\hline $\mathrm{PH}$ & $2.05 a$ & $1.78 b$ & $1.71 b$ & $1.79 b$ & $1.79 b$ & $1.74 b$ & $1.83 b$ & $1.73 b$ & $1.72 b$ \\
\hline SD & $22.36^{\text {ns }}$ & 21.85 & 20.47 & 20.08 & 21.14 & 20.63 & 18.42 & 20.30 & 17.86 \\
\hline NGR & $29.25 a$ & $23.20 \mathrm{~b}$ & $22.90 \mathrm{~b}$ & $23.70 b$ & $23.75 b$ & $20.00 c$ & $21.47 c$ & $19.87 \mathrm{c}$ & $21.80 c$ \\
\hline EL & $13.30 a$ & $11.00 \mathrm{~b}$ & $11.20 b$ & $11.06 \mathrm{~b}$ & $11.43 b$ & $9.28 c$ & $10.15 c$ & $8.88 c$ & $10.78 b$ \\
\hline \multicolumn{10}{|c|}{$2015 / 16$} \\
\hline $\mathrm{PH}$ & $1.75^{\mathrm{ns}}$ & 1.55 & 1.58 & 1.60 & 1.47 & 1.60 & 1.60 & 1.53 & 1.57 \\
\hline SD & $21.85^{\text {ns }}$ & 20.26 & 20.00 & 21.47 & 18.88 & 20.61 & 21.01 & 20.09 & 20.38 \\
\hline $\mathrm{GR}$ & $30.75 a$ & $23.55 b$ & $23.90 \mathrm{~b}$ & $24.97 \mathrm{~b}$ & $23.27 b$ & $25.30 \mathrm{~b}$ & $23.12 b$ & $24.22 b$ & $24.52 b$ \\
\hline EL & $15.82 a$ & $13.10 \mathrm{~b}$ & $11.92 b$ & $13.26 \mathrm{~b}$ & $12.56 \mathrm{~b}$ & $12.80 \mathrm{~b}$ & $12.42 \mathrm{~b}$ & $13.20 \mathrm{~b}$ & $12.47 \mathrm{~b}$ \\
\hline \multicolumn{10}{|c|}{$2016 / 17$} \\
\hline $\mathrm{PH}$ & $1.98 a$ & $1.65 a$ & $1.57 \mathrm{~b}$ & $1.59 b$ & $1.68 b$ & $1.98 a$ & $1.63 b$ & $1.60 \mathrm{~b}$ & $1.61 b$ \\
\hline SD & $22.20^{\text {ns }}$ & 22.27 & 20.37 & 20.47 & 19.06 & 22.48 & 20.99 & 20.67 & 22.40 \\
\hline NGR & $26.35 a$ & $21.50 \mathrm{~b}$ & $16.40 \mathrm{~b}$ & $18.32 \mathrm{~b}$ & $19.42 b$ & $24.75 a$ & $19.40 \mathrm{~b}$ & $18.57 \mathrm{~b}$ & $20.02 b$ \\
\hline EL & $14.99^{\text {ns }}$ & 13.07 & 11.06 & 12.15 & 12.60 & 15.02 & 11.55 & 11.61 & 12.77 \\
\hline \multicolumn{10}{|c|}{$2017 / 18$} \\
\hline $\mathrm{PH}$ & $2.32 a$ & $1.57 b$ & $1.19 c$ & $1.26 c$ & $1.23 c$ & $2.13 a$ & $1.20 c$ & $1.17 \mathrm{c}$ & $1.65 b$ \\
\hline SD & $25.22 a$ & $21.62 b$ & $19.02 b$ & $21.77 b$ & $21.66 b$ & $25.01 a$ & $21.29 b$ & $19.40 \mathrm{~b}$ & $20.01 a$ \\
\hline NGR & $34.62 a$ & $24.17 b$ & $23.25 b$ & $24.17 b$ & $22.67 \mathrm{~b}$ & $31.07 a$ & $24.42 b$ & $20.40 \mathrm{~b}$ & $25.10 b$ \\
\hline EL & $19.27 a$ & $14.35 b$ & $14.05 b$ & $14.29 b$ & $13.62 b$ & $18.25 a$ & $14.24 b$ & $12.19 b$ & $15.02 \mathrm{~b}$ \\
\hline
\end{tabular}

$\mathrm{PH}=$ plant height $(\mathrm{m}) ; \mathrm{SD}=$ stem diameter $(\mathrm{mm}) ; \mathrm{NGR}=$ number of grains per row; $\mathrm{EL}=$ ear length ( $\mathrm{cm}$ ). Means followed by the same lower-case letter in the row, do not differ significantly from each other, by the Scott-Knott test at $5 \%$; ns = not significant.

providing greater resistance to lodging. Sangoi et al. (2001) observed that the SD is a parameter that refers to the support and development capacity because plants with a higher SD have a higher rate of translocation of solutes, effectively contributing to nutrition and, consequently, productivity. Ribeiro et al. (2018) and Besen et al. (2020) also observed that N was essential to increase the SD and the EL of maize, thus, the largest SD and EL are attributed due to the ability of vetch to make $\mathrm{N}$ available for maize.

Parameters such as EL and NGR contribute directly to increase maize grain yield, a greater EL promotes more space available for development and filling of the grains and there is a supply of $\mathrm{N}$ and sufficient rainfall to meet the crop needs, as observed in this experiment (Fig. 1). Lourente et al. (2007) and Santos et al. (2010) observed that the use of green fertilizers influenced the EL and this variable is important to determine the potential productive of maize. In addition, Balbinot Junior et al. (2005) observed that the NGR had a great participation in maize grain yield, demonstrating the importance of increasing these morphological variables with a sufficient supply of $\mathrm{N}$ from cover crops such as vetch.

In addition to the single cultivation of vetch, the mix (vetch with black oats) also promoted increases in maize yield in the last two growing seasons (Figs. 2d, e) and increased some morphological parameters (Table 3). There was an increase in PH and NGR in the 2016/2017 and in the 2017/2018 crop seasons for all morphological variables, where the values were 
similar to the single cultivation of vetch. These increments in the mix may be related to the combined effect between the supply of $\mathrm{N}$ in the short term by residues with low $\mathrm{C} / \mathrm{N}$ ratio of vetch and the gradual release of $\mathrm{N}$ by residues with a high $\mathrm{C} / \mathrm{N}$ ratio of black oats. This dyssynchrony can be beneficial when most of the $\mathrm{N}$ from the mineralization of vetch residues is made available in the first 30 days of crop development, which is a critical period for the differentiation and definition of some of the maize yield components (Magalhães et al. 2002). The lower availability of $\mathrm{N}$ from the mineralization of oat residues is available to complement the nutritional demand in advanced stages of maize development (Acosta et al. 2014).

Surprisingly, the use of red clover was not able to promote a high level of productivity in the maize crop and, in general, it did not affect the morphological parameters. The hypothesis is that the red clover could promote increases on maize yields like those promoted by vetch by fixing considerable amounts of $\mathrm{N}$ in the soil. However, despite its capacity, the red clover did not develop well in the field, promoting a lower residue input along the years of experiment (Table 2). Locatelli et al. (2020) found a similar result for the soil carbon stocks in the same study area, where a stock of $\sim 96 \mathrm{mg} \cdot \mathrm{ha}^{-1}$ (0-60 m layer) was obtained for the red clover, against $\sim 107 \mathrm{mg} \cdot \mathrm{ha}^{-1}$ (0-60 m layer) for vetch. The same was observed in crops of the brassica's family (fodder radish and canola), despite not biologically fixing $\mathrm{N}$ like the legumes, those crops were expected to increase $\mathrm{N}$ cycling from deeper layers to the soil surface (Silva et al. 2007) and then make it available to maize uptake. However, those crops also had a poor development in the field and produced low amounts of dry matter (Table 2).

On the other hand, the continuous cultivation of grasses as cover crops showed a decrease in maize yields throughout the crop seasons (Fig. 2). This pattern can be justified by the continuous maintenance of a system based on the high addition (Table 2 ) of $\mathrm{N}$-poor residues ( $\mathrm{C} / \mathrm{N}$ ratio $>30)$, which can generate a temporary deficit in its availability (negative priming effect), allied to the lack of maize $\mathrm{N}$ fertilization. In these species (grasses), 40 to $75 \%$ of the $\mathrm{N}$ present in the tissues remained associated with the straw even 90 days after the deposition of the material on the soil (Oliveira et al. 2016). Nonetheless, the high SOM content $\left(44.23 \mathrm{~g} \cdot \mathrm{dm}^{-3}\right)$ in this clayey soil may have reduced the lack of $\mathrm{N}$ for maize demands in the first years of experimentation, as it was expected to provide certain amount from mineralization (Besen et al. 2020) and maize yield was less reduced, when compared to vetch (Figs. 2a, b). However, after 3 years of consecutive use of grasses as cover crops, the lack of $\mathrm{N}$ addition started to strongly reduce maize productivity.

Viola et al. (2013) observed a decline in maize productivity when grown in succession to black oats, white oats and ryegrass. Although the exclusive use of grasses as winter cover crops may not be interesting for increasing long-term maize productivity, other benefits can be attributed to the maintenance of soil cover by the straw, such as soil physical protection against erosion and runoff, reduction of thermal amplitude and the increase in soil carbon content (Balota et al. 2014). Moreover, the use of mineral $\mathrm{N}$ application in maize topdressing can be used to improve grain yield when gown in succession to black oats, as observed in this same region and soil conditions (Ribeiro et al. 2018; Besen et al. 2020).

Considering the importance of cover crop plants in the supply of nutrients for maize, especially $\mathrm{N}$, it is necessary to emphasize the importance of choosing adequate cover crop species for winter cultivation. This is relevant even in a soil managed in no-tillage system and with high SOM content $\left(44.23 \mathrm{~g} \cdot \mathrm{dm}^{-3}\right)$, which can supply partially the $\mathrm{N}$ demands of maize. However, in the medium to long term, might reduce the soil carbon stocks (Locatelli et al. 2020) and therefore, the supply of $\mathrm{N}$ to maize. Still, it is necessary to expand the results of the research, with the disclosure not only of the importance of cultivating cover crops instead of fallow to avoid soil degradation, but their relative contribution to plant nutrition and the total or partial replacement of mineral fertilizers, which lowers costs.

\section{CONCLUSION}

In a condition of high SOM content, the cultivation of maize without mineral $\mathrm{N}$ fertilization in succession to vetch, as winter cover crop, resulted in greater grain yields during five consecutive crop seasons. On the other hand, the use of vetch in a mix with black oats only presented benefits for maize after the third crop season.

Growing maize in succession to black oats, canola, fodder radish and red clover after five years showed superior development when compared to the fallow. However, the cultivation of these cover crops shows instability in maize yield in years with adverse climatic conditions. 


\section{AUTHOR'S CONTRIBUTION}

Conceptualization: Piva J. T.; Methodology: Piva J. T., Ribeiro R. H., Bratti F. and Locatelli J. L.; Investigation: Piva J. T., Ribeiro R. H., Bratti F., Locatelli J. L., Brancaleoni E. and Besen M. R.; Writing - Original Draft: Piva J. T., Ribeiro R. H., Bratti F., Locatelli J. L., Schmitt D. E. and Besen M. R.; Writing - Review and Editing: Piva J. T., Ribeiro R. H., Bratti F. and Locatelli J. L.; Resources: Piva J. T.; Supervision: Piva J. T.

\section{DATA AVAILABILITY STATEMENT}

Data will be available upon request.

\section{FUNDING}

Not applicable.

\section{ACKNOWLEDGMENTS}

Not applicable.

\section{REFERENCES}

[CONAB] Companhia Nacional de Abastecimento. (2019). Acompanhamento da Safra Brasileira de Grãos: V.6 - Safra $2018 / 19$ - N.9 Nono levantamento. Brasília: CONAB.

[FAO] Food and Agriculture Organization of the United Nations. (2019). Food Outlook: Biannual Report on Global Food Markets. Rome: FAO. [Accessed Feb. 27, 2020]. Available at: http://www.fao.org/3/ca6911en/CA6911EN.pdf

[USDA] United States Department of Agriculture. (2020). Crop Production. 2019 Sumary. Washington: USDA. [Accessed Feb. 27, 2020]. Available at: https://www.nass.usda.gov/Publications/Todays_Reports/reports/cropan20.pdf

Acosta, J. A. A., Amado, T. J. C., Silva, L. S., Santi, A., and Weber, M. A. (2014). Decomposição da fitomassa de plantas de cobertura e liberação de nitrogênio em função da quantidade de resíduos aportada ao solo sob sistema plantio direto. Ciência Rural, 44, 801-809. https://doi.org/10.1590/S0103-84782014005000002

Aita, C. (1997). Dinâmica do nitrogênio no solo durante a decomposição de plantas de cobertura: Efeito sobre a disponibilidade de nitrogênio para a cultura em sucessão. In M. R. Fries, and R. S. D. Dalmolin (Coords.), Atualização em recomendação de adubação e calagem: ênfase em plantio direto. (p. 76-111). Santa Maria: Universidade Federal de Santa Maria.

Aita, C. and Giacomini, S. J. (2003). Decomposição e liberação de nitrogênio de resíduos culturais de plantas de cobertura de solo solteiras e consorciadas. Revista Brasileira de Ciência do Solo, 27, 601-612. https://doi.org/10.1590/S0100-06832003000400004

Alva, A. K., Paramasivam, S., Fares, A., Delgado, J. A., Mattos Junior, D., and Sajwan, K. (2006). Nitrogen and Irrigation Management Practices to Improve Nitrogen Uptake Efficiency and Minimize Leaching Losses. Journal of Crop Improvement, 15, 369-420. https://doi. org/10.1300/J411v15n02 11 
Amado, T. J. C., Mielniczuk, J., and Aita, C. (2002). Recomendação de adubação nitrogenada para o milho no RS e SC adaptada ao uso de culturas de cobertura do solo, sob sistema plantio direto. Revista Brasileira de Ciência do Solo, 26, 241-248. https://doi.org/10.1590/ S0100-06832002000100025

Assmann, T. S., Assmann, A. L., Soares, A. B., Cassol, L. C., Giasson, M. S., and Giasson, N. F. (2007). Fixação biológica de nitrogênio por plantas de trevo (Trifolium spp.) em sistema de integração lavoura-pecuária para o sul do Brasil. Revista Brasileira de Zootecnia, 36, 1435-1442. https://doi.org/10.1590/S1516-35982007000600029

Balbinot Junior, A. A., Backes, R. L., Alves, A. C., Ogliari, J. B., and Fonseca, J. A. (2005). Contribuição de componentes de rendimento na produtividade de grãos em variedades de polinização aberta de milho. Revista Brasileira de Agrociência, 11, 161-166.

Balbinot Junior, A. A., Moraes, A., Pelissari, A., Dieckow, J., and Veiga, M. (2008). Formas de uso do solo no inverno e sua relação com a infestação de plantas daninhas em milho (Zea mays) cultivado em sucessão. Planta Daninha. 26, 569-576. https://doi.org/10.1590/ S0100-83582008000300012

Balota, E. L., Calegari, A., Nakatani, A. S., and Coyne, M. S. (2014). Benefits of winter cover crops and no-tillage for microbial parameters in a Brazilian Oxisol: A long-term study. Agriculture, Ecosystems \& Environment, 197, 31-40. https://doi.org/10.1016/j.agee.2014.07.010

Besen, M. R., Ribeiro, R. H., Goetten, M., Fioreze, S. L., Guginski-Piva, C. A., and Piva, J. T. (2020). Produtividade de milho e retorno econômico em sistema integrado de produção com doses de nitrogênio. Revista de Ciências Agroveterinárias, 19, 94-103. https://doi. org/10.5965/223811711912020094

Bisognin, M. B., Santi, A. L., Corassa, G. M., Gaviraghi, R., and Bisognin, F. B. (2014). Sistemas de cobertura do solo e doses de nitrogênio em milho safrinha na região norte do rio grande do sul. Enciclopédia Biosfera, 10, 1967-1707.

Borkert, C. M., Gaudêncio, C. A., Pereira, J. E., Pereira, L. R., and Oliveira Junior, A. (2003). Nutrientes minerais na biomassa da parte aérea em culturas de cobertura de solo. Pesquisa Agropecuária Brasileira, 38, 143-153. https://doi.org/10.1590/S0100-204X2003000100019

Cabezas, W. A. R. L., Alves, B. J. R., Caballero, S. S. U., and Santana, D. G. (2004). Influência da cultura antecessora e da adubação nitrogenada na produtividade de milho em sistema plantio direto e solo preparado. Ciência Rural, 34,1005-1013. https://doi.org/10.1590/ S0103-84782004000400006

Ciampitti, I. A. and Vyn, T. J. (2013). Grain Nitrogen Source Changes over Time in Maize: A Review. Crop Science, 53, 366-377. https:// doi.org/10.2135/cropsci2012.07.0439

Koehler, P. and Wieser, H. (2013) Chemistry of Cereal Grains. In Handbook on Sourdough Biotechnology (11-45). Boston: Springer. https://doi.org/10.1007/978-1-4614-5425-0_2

Kramberger, B., Gselman, A., Janzekovic, M., Kaligaric, M., and Bracko, B. (2009). Effects of cover crops on soil mineral nitrogen and on the yield and nitrogen content of maize. European Journal of Agronomy, 31, 103-109. https://doi.org/10.1016/j.eja.2009.05.006

Kuzyakov, Y., Friedel, J. K., and Stahr, K. (2000). Review of mechanisms and quantification of priming effects. Soil Biology and Biochemistry, 32, 1485-1498. https://doi.org/10.1016/S0038-0717(00)00084-5

Locatelli, J. L., Bratti, F., Ribeiro, R. H., Besen, M. R., Brancaleoni, E., and Piva, J. T. (2020). Soil carbon sequestration and stocks: shortterm impact of maize succession to cover crops in Southern Brazil Inceptisol. Spanish Journal of Agricultural Research, 18. https://doi. org/10.5424/sjar/2020183-16255

Lourente, E. R. P., Ontocelli, R., Souza, L. C. F., Gonçalves, M. C., Marchetti, M. E., and Rodrigues, E. T. (2007). Culturas antecessoras, doses e fontes de nitrogênio nos componentes de produção do milho. Acta Scientiarum. Agronomy, 29, 55-61. https://doi.org/10.4025/ actasciagron.v29i1.66

Magalhães, P. C., Durães, F. O. M., Carneiro, N. P., and Paiva, E. (2002). Fisiologia do Milho [Circular Técnica 22]. Embrapa. [Accessed Mar. 23, 2020]. Available at: http://docsagencia.cnptia.embrapa.br/milho/circul22.pdf 
Michelon, C. J., Junges, E., Casali, C. A., Pellegrini, J. B. R., Rosa Neto, L., Oliveira, Z. B., and Oliveira, M. B. (2019). Soil attributes and yield of corn cultivated in succession to winter cover crops. Revista de Ciências Agroveterinárias, 18, 230-239. https://doi. $\operatorname{org} / 10.5965 / 223811711812019230$

Oliveira, R. A., Brunetto, G., Loss, A., Gatiboni, L. C., Kürtz, C., Müller Junior, V., Lovato, P. E., Oliveira, B. S., Souza, M., and Comin, J. J. (2016). Cover Crops Effects on Soil Chemical Properties and Onion Yield. Revista Brasileira de Ciência do Solo, 40, 1-17. https://doi. org/10.1590/18069657rbcs20150099

Palm, C., Blanco-Canqui, H., DeClerck, F., Gatere, L., and Grace, P. (2014). Conservation agriculture and ecosystem services: An overview. Agriculture, Ecosystems \& Environment, 187, 87-105. https://doi.org/10.1016/j.agee.2013.10.010

Ribeiro, R. H., Besen, M. R., Fioreze, S. L., and Piva, J. T. (2018). Management of nitrogen fertilization in maize cultivated in succession to black oats in a temperate climate. Comunicata Scientiae, 9, 202-210. https://doi.org/10.14295/cs.v9i2.2585

Sangoi, L, Almeida, M. L., Lech, V. A., Gracietti, L. C., and Rampazzo, C. (2001). Desempenho de híbridos de milho com ciclos contrastantes em função da desfolha e da população de plantas. Scientia Agricola, 58, 271-276. https://doi.org/10.1590/S0103-90162001000200009

Santos, P. A., Silva, A. F., Carvalho, M. A. C., and Caione, G. (2010). Adubos Verdes e Adubação Nitrogenada em Cobertura no Cultivo do Milho. Revista Brasileira de Milho e Sorgo, 9, 123-134. https://doi.org/10.18512/1980-6477/rbms.v9n2p123-134

Silva, A. A., Silva, P. R. F., Suhre, E., Argenta, G., Strieder, M. L., and Rambo, L. (2007). Sistemas de cobertura de solo no inverno e seus efeitos sobre o rendimento de grãos do milho em sucessão. Ciência Rural, 37, 928-935. https://doi.org/10.1590/S0103-84782007000400002

Silva, A. A., Silva, P. R. F., Sangoi, L., Piana, A. T., Strieder, M. L., Jandrey, D. B., and Endrigo, P. C. (2008). Produtividade do milho irrigado em sucessão a espécies invernais para produção de palha e grãos. Pesquisa Agropecuária Brasileira, 43, 987-993. https://doi.org/10.1590/ S0100-204X2008000800006

Soil Survey Staff, 2014. Keys to Soil Taxonomy, 12th ed. USDA-Natural Resources Conservation Service, Washington, DC.

Tiecher, T., Calegari, A., Caner, L., and Rheinheimer, D. S. (2017). Soil fertility and nutrient budget after 23-years of different soil tillage systems and winter cover crops in a subtropical Oxisol. Geoderma. 308, 78-85. https://doi.org/10.1016/j.geoderma.2017.08.028

Veloso, M. G., Angers, D. A., Tiecher, T., Giacomini, S., Dieckow, J., and Bayer, C. (2018). High carbon storage in a previously degraded subtropical soil under no-tillage with legume cover crops. Agriculture, Ecosystems \& Environment, 268, 15-23. https://doi.org/10.1016/j. agee.2018.08.024

Viola, R., Benin, G., Cassol, L. C., Pinnow, C., Flores, M. F., and Bornhofen, E. (2013). Adubação verde e nitrogenado na cultura do trigo em plantio direto. Bragantia, 72, 90-100. https://doi.org/10.1590/S0006-87052013005000013 